\title{
Designing Social Campaign Healthy Life Style for HIV/AIDS Prevention Through Muaythai
}

\author{
Fildzah Shabrina Firdaus ${ }^{1}$, Jiwa Utama ${ }^{2}$ \\ ${ }^{1}$ Visual Communication Design, Telkom University, Bandung, Indonesia \\ finafildzahs@gmail.com, jiwautama@gmail.com
}

\begin{abstract}
The number of those who suffer HIV/AIDS in Indonesia especially in Bandung is gradually increasing each year. This was caused by lack of awareness about HIV/AIDS causes, so they are still doing risky things. Teenagers and early adulthood are very worrying, because the most number of those who suffer HIV/AIDS is 20-29 years. Their dreams could be hampered because what they have done. With qualitative method of research, and communication strategy AISAS, it have came to the result that the way to deliver the information and education about HIV/AIDS along with the prevention is by designing a social campaign through living healthy, aims to divert their bad activities. The medias could be formed in such a chain of events like public event, video, print-ad, and some of the other proponent medias.
\end{abstract}

Keywords Social Campaign, HIV/AIDS, Living Healthy, Prevention, Divert

\section{Introduction}

HIV/AIDS is one of the top 10 deadliest diseases in the world. HIV/AIDS in Indonesia is one of Asia's fastest growing epidemics, especially in Bandung City is gradually each year. Bandung is the highest total HV/AIDS case in Jawa Barat, and fourth place in Indonesia. In 2016 total number of HIV/AIDS cases was 3960. The highest rate occurring among those aged 20-29 (48,1\%). And causes, firstly because using injection drug (44,1\%), then heterosexual $(36,9 \%)$, and homosexual $(10,9 \%)$. The main cause of this cause was bad lifestyle and bad environment like love to get over being drunk then do free sex with many girls or boys. Or sharing drug syringes. Less awareness, and less education about HIV/AIDS causes.

The right designing social campaign to create awareness especially for youths in Bandung City to prevent HIV/AIDS is to change their bad lifestyle become better lifestyle with sports and accompanied with education.

\section{Theoretical Background}

Social Campaign is an action that has a purpose to make some people have better mindsets with attractively packaged, there are moral values, prejudice and appeal. (Andrews, 2008:8)

According to Miller (1996) in Suryanto book (2015:51) communication is the center of attention in human behavior situation which has as purpose for influence behavioral intention by slimming some messages to receiver.

According to Anny Noor (2013:8), event is an activity which has some purposes and benefits
Tom Duncan defines media strategy as an idea or thought about how the purpose of media will be reach by selection of some media combiantions. (Morrissan, 2010: 218). Your goal is to adhere to this paper in appearance as closely as possible.

In promotion activity, campaign can't released from the power of communication and visual, it's the main thing to deliver the message for target audiences to be understood. (Supriyono, 2011: 57)

HIV or Human Immunodeficiency Virus, is virus that attacks the immune system, which is our body's natural defence against illness. AIDS or Acquired Immune Deficiency Syndrom is a disease in which there is a severe loss of the body's cellular immunity, greatly lowering the resistance to infection and malignancy. AIDS will appear after the virus (HIV) attacks our immune system for five to ten years or more. HIV virus does not work quickly. This asymptomatic period can be 3 - 5 years and even more. Living a life to be People with HIV / AIDS should do a good and balanced way because it is very useful for health and prolong the period without these symptoms. Eat nutritious, balanced work and rest, no stress, moderate exercise and sleep disorder. (Suzana, 2009: 8-9).

Sport is a set of motions that are already set and planned to improve the quality of life. (Giriwijoyo, 2007:85)

The visual style chosen for this campaign is to utilize photographic techniques with an emotional approach. The more dominant color used is red. Because reds are the color of fire, morning sun, and blood, giving the impression of warmth, happiness, courage, spirit, strength, fight, and red also symbolize the color of AIDS tape. Meanwhile, white means, sterile, healthy clean. Each layout will have a red box indicating that it is a poster of AISATION. 


\section{I The Research Method}

To complement the data in the design of the HIV / AIDS prevention campaign, it involves a qualitative method of research in which the method is to use natural methods, to examine itself as a key instrument, data technique combined, inductive important analysis, and meaning will be more emphasized The results of the study were compared with generalizations. (Sugiyono, 2015:1).

\section{Result and Discussion}

This campaign will be communicated using an emotional and lifestyle approach that will be tailored to the target audience, then provide information about HIV / AIDS education so they can prevent that and know. Through the appropriate communication approach, it is expected that the message and the purpose of the campaign can touch the heart of the target, so that the information has been given can be received well then can prevent what should be prevented

Message:

"Berudakasilah dan ubah gaya hidup lebih sehat dari sekarang untuk melawan datangnya HIV/AIDS."

And can be shortened "Gaya hidup sehat cegah HIV / AIDS".

The purpose of making this message is to invite target audience to fight HIV / AIDS diseases and live their activities to be healthier, thus diverting from risky activities.

To design a campaign, it takes a name that will be part of the campaign logo. The name for this campaign is AISATION or "Against AIDS with Sport and Education". With the tagline "Lawan sebelum dilawan".

Creative strategies that will be used is to pack information and convey the message creatively and keep educating. Because this campaign is educative, so that the target audience could be aware and know the information prevention of HIV / AIDS, and how the virus can be infected. And the culmination of this campaign is to invite the target audience to live healthy.

The campaign selected several media to disseminate or communicate "Lawan Sebelum Dilawan". Media determination using AISAS method (Attention Interest Search Action Share), and this is measured from the needs and usefulness of the media in this campaign activity. This media is selected based on observations made;

Table 1. AISAS

\begin{tabular}{|l|l|l|l|l|}
\hline Attention & \multicolumn{1}{|c|}{ Interest } & Search & Action & \multicolumn{1}{|c|}{ Share } \\
\hline Poster & Event 1 & Social & Event2 & Word of \\
Teaser & Merchendis & Media & & Mouth \\
Video & e & Website & & Social Media \\
Teaser & Sticker & & & \\
Billboard & Flyer & & & \\
& Buzzer & & & \\
& & & & \\
\hline
\end{tabular}

The visual style chosen for this campaign is to utilize photographic techniques with an emotional approach. The more dominant color used is red. Because red color has meaning fire color, morning sun, and blood color, giving the impression of warmth, happiness, courage, spirit, strength, fight, and red color also symbolize the color of AIDS tape. Then use a white color that means, sterile, healthy clean. Each layout will have a red box indicating that it is a poster of AISATION.

This campaign is targeted to young people especially in Bandung, 18-24 years old. Their psychographic is productive, active, following trend. Having behavioral active, easily affected, love to hang out. And the insight is target audience will be aware about how risk HIV/AIDS, then they can fight and prevent it.

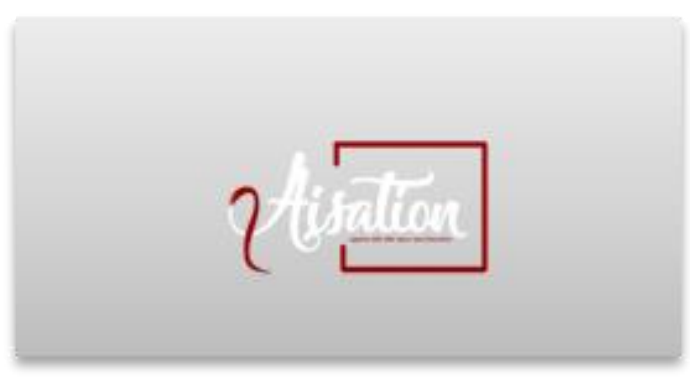

Figure 1. Campaign Logo

This logo means "Dare to fight AIDS to be healthy and secure your life. The combination of colors used is also only red, white. Red symbolizes bold, white symbolizes clean, sterile, and healthy. Box shapes used in the logo can be safely interpreted. The box is placed in the "SATION" section because the one who secures them from HIV / AIDS is Education and Sport

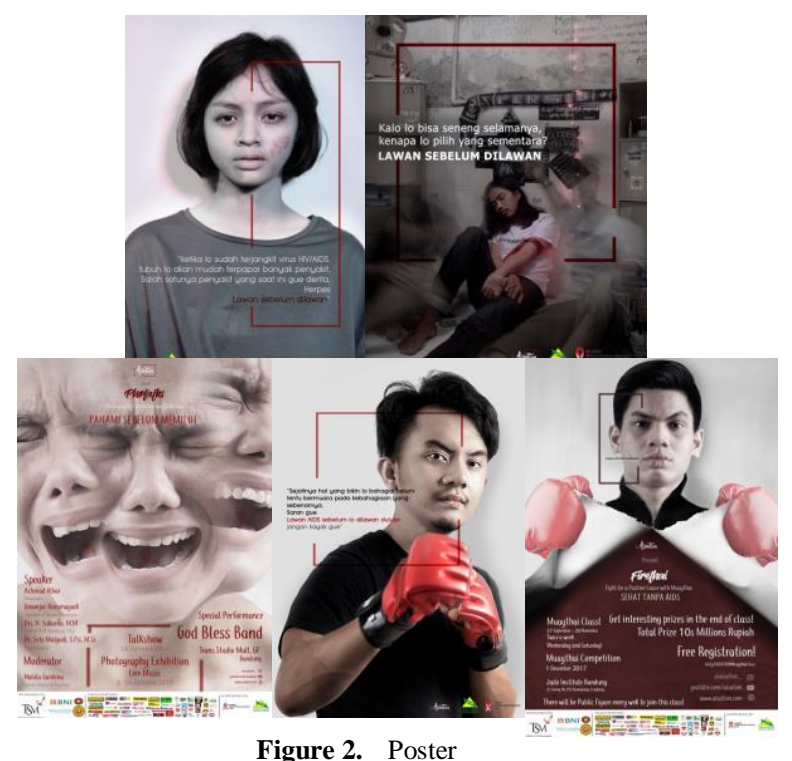

Those posters are teaser, informing, reminding and for event 


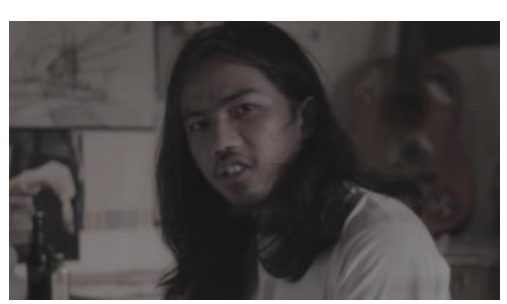

Figure 3. Video Teaser

This video is telling a dead person then tell a little about his former life.

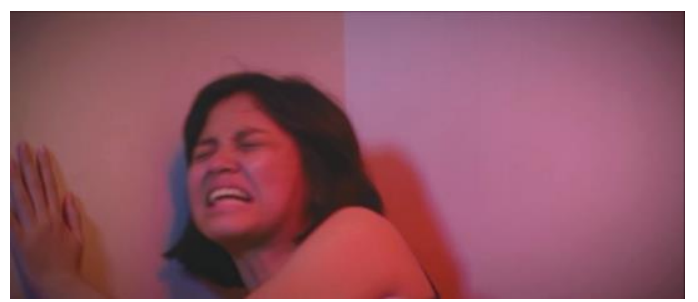

Figure 4. Informing

This video is showing HIV/AIDS causes.

\section{Conclusion}

To recover rapidly the number of HIV / AIDS sufferers in Bandung, the author make an idea by presenting the young people with interesting educations packaged, then switching their lifestyle into more positive lifestyle such as exercise, because a healthy body will affect the mind and our mindset. Aisation or Against AIDS with Sport and Education will be present to provide services for young people aged 18-24 years to avoid this terrible virus.

Viruses that we already know the danger but always increased should be noted more. For the government to have more socialization for young people, so they can also feel cared for. Because young people should be protected, if not they who will continue the nation.

\section{ACKNOWLEDGEMENT(S)}

The author want to say thank you for all interviewees to gave a lot data, so this Final Project can be resolved properly.

\section{REFERENCES}

[1] Any Noor. 2013. Manajemen Event. Bandung : Alfabeta.

[2] Moriarty, dkk. 2011. Advertising. Jakarta: Kencana Prenada Media Group.

[3] Morissan, 2010. Periklanan, Komunikasi Pemasaran Terpadu. Jakarta: Kencana Prenada Media Group.

[4] Sefrina, Andin. 2016. Osteoporosis -The Silent Disease. Yogyakarta, Rapha Publishin Supriyono, Rakhmat. 2010. Desain Komunikasi Visual - Teori dan Aplikasi. Yogyakarta, Andi g.
[5] Sugiyono. 2016. Metode Penelitian Kuantitatif, Kualitatif, dan R\&D. Bandung, ALFABETA.

[6] Suzana, dkk, 2009 Hidup dengan HIV/AIDS, Jakarta : Yayasan Spiritia

[7] Venus, A. 2012. Manajemen Kampanye. Bandung, Simbiosa Rekatama Media.

[8] Andrews, Marc. 2008. Social Campaigns: Art of Visual Persuasion: It's Psychology, Its Semiotics, Its Rethoric. http://www.mahku.nl/download/m_andrews_socialcampai gns.pdf 